\title{
FRAGMENTOS: QUANTO COMO UMA FOLHA. ENTREVISTA COM DONNA HARAWAY
}

\author{
Donna J. Haraway \\ Thyrza Nichols Goodeve
}

$\mathbf{P}$ rofessora Emérita no Programa de História da Consciência da Universidade da Califórnia em Santa Cruz, Donna Haraway é uma das pensadoras mais diz respeito a uma perspectiva crítica sobre a tecnociência contemporânea. ${ }^{2}$

Apresentamos aqui a tradução de alguns trechos de uma entrevista conduzida por Thyrza Nichols Goodeve, e divulgada inicialmente no catálogo Fleshfactor do festival Ars Electronica de 1997. Embora a edição inglesa dessa entrevista, publicada no livro How Like a Leaf, já tenha completado quinze anos, a conversa condensa informações preciosas sobre o percurso pessoal-intelectual

\footnotetext{
${ }^{1}$ Fragmentos publicados originalmente em How like a leaf: an interview with Thyrza Nichols Goodeve / Donna J. Haraway. New York and London: Routeldge, 1999. A Comissão Editorial e as organizadoras do dossiê agradecem às autoras, Donna Haraway e Thyrza Goodeve, e à editora Baldini \& Castoldi pela autorização para traduzir para o português os trechos ora publicados. Tradução de Pedro Peixoto Ferreira e André Favilla, revisão técnica de Daniela Tonelli Manica e Martha Ramírez-Gálvez.

${ }^{2}$ No período que se sucedeu à publicação desta entrevista, Donna Haraway publicou mais dois livros dedicados à discussão sobre (outros) animais e espécies companheiras: The Companion Species Manifesto: Dogs, People, and Significant Otherness, Chicago: Prickly Paradigm Press, 2003; e When Species Meet, Minnesota: University of Minnesota Press, 2008. Um dos capítulos deste último foi traduzido e publicado em: HARAWAY, Donna. A partilha do sofrimento: relações instrumentais entre animais de laboratório e sua gente. Horizontes antropológicos, Porto Alegre, v. 17, n. 35, p. 27-64, Junho, 2011.
} 
de Haraway, bem como alguns de seus principais pressupostos e o estilo peculiar com o qual contribui para uma apreensão feminista da tecnociência.

0 texto que se segue é uma compilação de partes do segundo, quarto e quinto capítulos dessa entrevista, intituladas respectivamente: Organicismo como teoria crítica; Mais do que metáfora; Prática mundana; Ele não nasceu num jardim, mas certamente nasceu numa história; Quanto como uma folha; e Testemunha Modesta.

\section{ORGANICISMO COMO TEORIA CRÍTICA}

Thyrza Nichols Goodeve: Vamos conversar sobre seus quatro livros do ponto de vista do presente. Gostaria de usá-los como dispositivos mnemônicos para descobrir capítulos em sua vida. O que foi colocado na realização de cada um deles e o que saiu? Especialmente porque parece haver evidentes conexões temáticas entre seu primeiro livro e seu livro mais recente - Crystals, Fabrics, and Fields $e$ Modest_Witness - $e$ também entre Primate Visions $e$ Simians, Cyborgs, and Women, dado que eles foram escritos simultaneamente nos anos 1980.

Donna J. Haraway: Um dos modos como vejo estes quatro livros quando eles estão alinhados em sequência é que contam uma narrativa histórica. Desde 0 início e até o presente, meu interesse tem se voltado para aquilo que acaba contando como natureza e para quem acaba habitando as categorias naturais. Mais do que isso, interesso-me por aquilo que está em jogo no julgamento sobre a natureza e por aquilo que está em jogo na manutenção das fronteiras entre 0 que é chamado de natureza e o que é chamado de cultura na nossa sociedade. E como os valores se invertem? Como funciona esse dualismo, entre natureza e sociedade ou natureza e cultura, tão importante em nossa história cultural e em nossa política?

TNG: Todos os quatro livros são diferentes maneiras de lidar com esse dualismo?

DH: Certo - todos os quatro livros são versões desse problema e todos eles o abordam por meio da biologia. Mas se por um lado a biologia é o princípio organizador central, por outro ela está sempre fortemente entrelaçada com questões de política e de prática semiótica, e também com diversas conexões transdisciplinares com literatura, antropologia e história. Mas a questão principal é a manutenção dessa junção muito potente entre fato e ficção, entre o literal e 0 figurativo ou tropológico, entre o científico e o expressivo. 
TNG: Foi uma análise tropológica o que você fez no primeiro livro?

DH: Certo, o primeiro livro, Crystals, Fabrics, and Fields: Metaphors of Organicism in Twentieth-Century Developmental Biology, discutiu três estruturas metafóricas que foram usadas para interpretar a forma biológica no século XX, a concepção para a formação e para o controle da forma biológica. "Cristais", "tecidos" e "campos" são todas metáforas não-reducionistas, querendo dizer, não-atomísticas, não-particularistas. São metáforas que lidam com totalidades complexas e com processos complexos. Em outras palavras, você não pode entender adequadamente a forma quebrando-a em suas menores partes e depois devolvendo-lhes suas relações.

TNG: Isso é muito importante para a sua teoria em geral, não é? Quase uma direção para as pessoas lerem o seu trabalho.

DH: Sim. Quando as pessoas perdem as relações, o todo, e focam apenas nos pedaços separados, surgem todos os tipos de leituras distorcidas de meu trabalho. Todas as minhas metáforas implicam em algum tipo de ação sinergética em um nível de complexidade que não é acessível por meio das suas menores partes. Portanto, elas são todas metáforas em torno da complexidade. Meu trabalho tem sempre sido sobre o que conta como natureza. De certa forma, sinto que escrevi sobre uma gama de tipos de naturezas. Escrevi sobre naturezas artefatuais nos diversos tipos de trabalhos ciborguianos que escrevi. Uma maneira de encarar esses livros é que Primate Visions, Simians, Cyborgs, and Women e Modest_Witness tratam de três tipos de entidades - cada um deles investiga diferentemente um conjunto de historicidades, de binarismos, de interfaces, de práticas de conhecimento. Embora ecoando um no outro, eles não são a mesma coisa. Modest_Witness é, de certo modo, o terceiro livro de uma trilogia. Cada um dos três volumes é composto por seus próprios ensaios e cada um destes tem sua própria história de publicação. Em todos os livros há muita coisa nova que nunca havia sido publicada antes, mas todos eles contêm ensaios que foram escritos e publicados em outras ocasiões. Cada um dos três livros faz algum trabalho dos outros também. Por exemplo, em Simians, Cyborgs, and Women, [os capítulos] "A Cyborg Manifesto"3 e "The Biopolitics of Postmodern Bodies" são dois ensaioschave, mas há também os ensaios sobre primatas e aqueles sobre gênero. Da mesma forma, em Primate Visions, há capítulos que enfatizam as qualidades ciborguianas da pesquisa sobre primatas. E em Modest_Witness há capítulos que

\footnotetext{
${ }^{3}$ Há tradução para o português: Manifesto ciborgue: ciência, tecnologia e feminismo-socialista no final do século XX. In: SILVA, Tomaz Tadeu da. Antropologia do ciborgue - as vertigens do póshumano. Belo Horizonte: Autêntica, 2000.
} 
enfatizam certos temas ciborguianos mas não o material sobre primatas. Contudo, muitas questões de saberes situados reemergem em Modest_Witness.

\section{MAIS DO QUE METÁFORA}

TNG: Gostaria que você, como uma crítica cultural, descrevesse a sua metodologia. O que me interessa particularmente é como seu treinamento como bióloga do desenvolvimento e bióloga molecular influenciou, não somente os temas de seu trabalho, mas a própria metodologia dele.

DH: Palavras como "metodologia" são muito assustadoras, você sabe! Em vez de "metodologia", preferiria dizer que tenho modos definidos de trabalhar que se tornaram mais conscientes com o passar dos anos. E é certo que o meu treinamento em biologia -molecular, celular e do desenvolvimento - importa muito para mim. Em particular, na maneira como me permite estar alerta aos seres biológicos e às redes biológicas de relação, tirando um tremendo prazer deles. Sou fascinada pela arquitetura interna das células e dos cromossomos. E não há dúvida de que eu frequentemente penso por metáforas biológicas.

TNG: Há um tipo de biologismo no modo como você escreve. Você pega alguma coisa - um objeto de conhecimento ou de cultura - e você vai mais e mais para dentro dela, para aquilo que é a sua estrutura. E então você se movimenta dentro de todo tipo de redes de significado que você descobre a partir daquela análise, e assim por diante. Você também utiliza bastante, na sua escrita, metáforas óticas e o seu método realmente tem um tipo de efeito de aproximação microscópica, sem, evidentemente, jamais deixar para trás o quadro mais amplo.

DH: Sou fascinada por mudanças de escala. Penso que os mundos biológicos convidam a pensar em, e sobre, diferentes tipos de escala. Ao mesmo tempo, mundos biológicos são plenos de imaginações e de seres desenvolvidos de mecanismos e de arquiteturas biológicas bastante extraordinárias. A biologia é uma fonte inesgotável para a tropologia. É certamente plena de metáfora, mas é mais do que metáfora.

TNG: Você já usou esta frase antes. O que você quer dizer por "é mais do que metáfora"?

DH: Quero dizer não somente as metáforas discursivas e fisiológicas que podem ser encontradas na biologia, mas as estórias. Por exemplo, todas as diferentes incongruências irônicas, quase engraçadas. A pura astúcia e 
complexidade disso tudo. De modo que a biologia não seja apenas uma metáfora que ilumina alguma outra coisa, mas uma fonte inesgotável de acesso à nãoliteralidade do mundo. E também, quero chamar a atenção para a simultaneidade do fato e da ficção, da materialidade e da semioticidade, do objeto e do tropo.

TNG: Você se refere ao modo como estas entidades biológicas literais são também metáforas tão poderosas para o entendimento da "vida"; i.e., sistemas ontológicos e biológicos. Penso na sua discussão do microorganismo Mixotricha paradoxa em "Cyborgs and Symbionts: Living Together in the New World Order", de The Cyborg Handbook. ${ }^{4}$

DH: Sim. Utilizo a Mixotricha paradoxa como uma entidade que interroga a individualidade e a coletividade ao mesmo tempo. Trata-se de um organismo unicelular microscópico que vive no intestino posterior do cupim da Austrália setentrional. Aquilo que conta como "ele" é complicado, pois ele vive em simbiose obrigatória com outros cinco tipos de entidades. Cada uma tem um nome taxonômico e cada uma se relaciona estreitamente com bactérias, pois não possuem um núcleo celular. Elas possuem ácido nucléico, possuem DNA, mas este não é organizado em um núcleo. Cada um destes cinco tipos de coisas diferentes vive em ou sobre uma região diferente da célula. Por exemplo, um vive nas interdigitações da superfície exterior da membrana celular. De modo que você tem estas pequenas coisas que vivem nestas dobras da membrana celular e outras que vivem dentro da célula. Mas elas não são, no sentido pleno, parte da célula. Por outro lado, elas vivem em simbiose obrigatória. Ninguém pode viver independentemente aqui. Isso é co-dependência pra valer! E, então, a questão é ela é uma entidade ou seis? Mas seis tampouco está correto, pois há aproximadamente um milhão das cinco entidades anucleadas para cada célula mononuclear. Há múltiplas cópias. Então, quando é que um decide se tornar dois? Quando é que este conjunto completo se divide de modo que agora você tem dois conjuntos? E o que conta como Mixotricha? É somente a célula nucleada ou é conjunto todo? Obviamente, esta é uma fabulosa metáfora que é uma coisa real para interrogar nossas noções de um e de muitos.

TNG: Parece também que há um tipo de temporalidade multidimensional nela. Quero dizer, como alguém a encontra em primeiro lugar e qual era a sua aparência - que forma assumia - quando foi descoberta? Em qual momento de sua existência ela foi descoberta? E como os pesquisadores encontraram toda a sua complexidade e ainda a viram como

\footnotetext{
${ }^{4}$ Donna J. Haraway, prefácio a The Cyborg Handbook (1995a).
} 
um todo em vez de uma série de entidades diferentes? Não sei muito sobre biologia, mas minha intuição é que há todo tipo de coisas como a $\underline{M}$. paradoxa.

DH: Certo - há zilhões de exemplos. A biologia é um recurso infindável. Esta é a razão pela qual sempre preferi biologia à psicanálise, pois ela coloca para fora muito mais possibilidades para estórias que parecem alcançar algo de nossa existência política, psicológica, histórica. A psicanálise define tudo muito cedo ela pode ser parte da verdade, mas não é a parte mais interessante. Eu também simplesmente amo o nome Mixotricha paradoxa!

TNG: 0 que Mixotricha quer dizer?

DH: Fios misturados.

TNG: Isto é fabuloso. E Mixotricha é uma criatura de fronteira como o ciborgue, o primata e o OncoMouse ${ }^{T M}$ ?

DH: Certo, mas com o ciborgue e a criatura geneticamente construída você precisa pensar no industrial e no artefatual, no construído pelo humano. Com a Mixotricha isto não é verdade, embora ela de fato precise de um relacionamento íntimo com os processos laboratoriais que a trazem para a nossa vista. Nossa relação com $M$. paradoxa é produzida por relações tecnocientíficas que incluem a maquinaria laboratorial, viagens de avião, toda a história da zoologia e da taxonomia como também da ciência colonial na Austrália.

TNG: Você frequentemente recebe os mesmos tipos de leituras reducionistas de seu trabalho que narrativistas experimentais e artistas como Yvonne Rainer ${ }^{5}$ também recebem, por muitas das mesmas razões. Algumas pessoas se recusam a se engajar com o tipo de complexidade que seu uso de $\underline{M}$. paradoxa requer. Associo isto a uma estética anti-linear, anti-teleológica, quase experimental ou vanguardista (para empregar um velho termo) na sua teoria que se parece com a de Rainer. Como você, ela está constantemente construindo análises de raça, gênero, sexualidade, desejo, por meio de uma estética relacional-associativa complexa que exige que não se interrompa seu filme em momento algum e diga: Isto é uma afirmação de Yvonne Rainer. É o mesmo com o seu trabalho que, se lido com má-vontade, é transformado em uma visão da ciência anti-materialista, tecnofílica - ou tecnofóbica -

\footnotetext{
${ }^{5}$ Yvonne Rainer, bailarina, coreógrafa, artista, escritora, cineasta. MURDER and murder (1997) era, na ocasião da entrevista, seu mais recente filme. Para uma discussão de seu trabalho, ver Rainer (1997).
} 
construcionista social. Tais leituras são representativas de uma inabilidade de trabalhar com sutileza.

DH: É um tipo de mentalidade literal. E é por isso que figuras são tão importantes para mim, porque figuras são imediatamente complexas e nãoliterais, para não falar instâncias de real prazer na linguagem. Nota-se um estranho literalismo quando críticos criam posições que na verdade não existem como lendas urbanas recicladas de pessoas dizendo, "Você acredita em DNA!?!" Mas que falta de sofisticação! Isto é triste, revoltante, e retira todo o prazer em linguagem $e$ corpos que anima tanto do trabalho sério em estudos culturais da ciência. ${ }^{6}$

TNG: Encontrar o figurativo no literal, ou concreto, é muito importante para você. O seu livro recente: Modest_Witness@Second_Millennium.FemaleMan(c) _Meets_OncoMouse ${ }^{\mathrm{TM}}$ passa muito tempo discutindo- figuração, não somente nos discursos da biotecnologia mas na "carne" mesma do próprio gene. Estou interessada no modo como "carne" sempre foi importante para você - não apenas por meio de seu treinamento como uma bióloga molecular e bióloga do desenvolvimento, mas no seu profundo compromisso com a "carne" do gênero, da raça, da espécie. "Carne" funciona como uma sinédoque para a maneira como a realidade material significa ou é fisicamente "tropológica", como você diz.

DH: A primeira coisa que eu diria é que palavras são intensamente físicas para mim. Acho palavras e linguagem mais próximas à carne do que às ideias.

TNG: Roland Barthes tem esta ótima frase, "A linguagem é uma pele: esfrego minha linguagem contra a outra. É como se eu tivesse palavras em vez de dedos, ou dedos nas pontas de minhas palavras" (BARTHES, 1978, p. 73). De modo bem semelhante você conta com a suculência metafórica carnal da linguagem.

DH: Dado que eu experiencio a linguagem como um processo intensamente físico, não posso não pensar por meio de metáfora. Não é como se fizesse uma escolha de trabalhar com e por meio de metáfora, é que me experiencio dentro destes processos de semiose intensamente físicos, constantemente desviantes. Bioquímica e linguagem simplesmente não parecem tão diferentes para mim. Há também uma dimensão católica em tudo isto. A minha profunda formação em simbolismo e sacramentalismo católico -

${ }^{6}$ Ver Barbara Ehrenreich e Janet Macintosh (1997). 
doutrinas de encarnação e transubstanciação - foram todas intensamente físicas. A inexorável simbolização da vida católica não é somente anexada ao mundo físico, ela é 0 mundo físico. Olhe a arte religiosa do sudoeste dos Estados Unidos, a arte mexicana, latina e chicana, e você tem um exemplo intenso disto. Contraste esta arte com a arte protestante mais abstêmia e então imagine o interior de uma igreja na Cidade do México. Cresci em meio ao mundo da arte da Cidade do México, por assim dizer, embora tenha crescido em Denver, Colorado. Era uma cena católica irlandesa, em nada tão rica quanto a tradição cultural latina, mas cresci em grande parte dentro de um mundo narrativo figurado simbólico elaborado no qual as noções de signo e de carne estavam profundamente amarradas uma à outra. Eu entendi o mundo deste modo quando tinha quatro anos.

TNG: Você poderia definir carne?

DH: Meus instintos são sempre fazer a mesma coisa. É insistir na junção entre materialidade e semiose. Carne não é mais uma coisa do que um gene é. Mas a semiose materializada da carne sempre inclui os tons da intimidade, do corpo, do sangramento, do sofrimento, da suculência. Carne é sempre de algum modo úmida. Está claro que não se pode utilizar a palavra carne sem entender vulnerabilidade e dor.

TNG: Há esta citação que guardei de seu "A Manifesto for Cyborgs" de 1985 na qual você diz: "Por que nossos corpos deveriam terminar na pele ou incluir, na melhor das hipóteses, outros seres encapsulados pela pele"?

DH: E outros organismos assim como objetos construídos. Há todos os tipos de não-humanos com os quais nós estamos entrelaçados.

TNG: $E$ também os modos como a nossa carne é feita de carne artefatual. Estou pensando na forma como você emprega sinais sintáticos “@”, “( ), “TM" - em Modest_Witness@Second_Millennium.FemaleMan $@$ Meets_OncoMouse ${ }^{\mathrm{TM}}$ para nos localizar. É um exēmplo de como o seu título cria com sucesso um novo tipo de sintaxe e de figuração. O título "Modest Witness@Second Millennium.FemaleMan@ $\left(\right.$ Meets_OncoMouse $^{\mathrm{TM}} e^{e}$ seu próprio poema tecnocultural. Você visualiza $\bar{e}$ teoriza por meio das palavras e sinais sintáticos do título, situando-nos na bistória do final do século XX. Isto é maravilhoso porque estes sinais são as novas marcas [brands].

DH: Especialmente com o duplo sentido de marca como tipo e de marca de propriedade, queimada na carne. 
TNG: E em vez de usar a palavra pós-modernismo, ou qualquer outro tipo de categoria da modernidade para marcar a diferença constitucional entre o final do século XX e os momentos iniciais da modernidade, você diz, "Eu dou ao leitor um endereço de e-mail, se não uma senha, para situar as coisas na rede”. (HARAWAY, 1997, p. 43). E-mail é familiar para quase todo mundo hoje. É uma localização crucial para nós na vida cotidiana e significa um modo de comunicação particular à tecnocultura do final do século XX. “@” instancia todas as complexas redes de relação (econômicas, ontológicas, sociais, históricas, tecnológicas) que são cruciais para o pós-modernismo sem nos forçar mais uma vez ao engajamento em todos os ásperos debates acadêmicos em torno do termo.

DH: E é uma piada também.

TNG: Sim. Humor, tanto quanto ironia, é decisivo para seu estilo teórico. Como podemos não rir da descrição que você oferece da combinação transgênica anticongelante tomate-peixe desenvolvida em Oakland, Califórnia, em 1991. Dado que eu mencionei o pós-modernismo, estou interessada na sua definição de modernidade.

DH: Minha definição de modernidade é que ela é o período do transporte intensificado de sementes e de genes. Por exemplo, olhe para a invenção do primeiro grande sistema industrial - a agricultura de plantation (que não é uma ideia minha, mas que tomei de outros) - e siga todo o realocamento de populações, de plantas, de açúcar, de mandioca, para alimentar as populações das quais a força de trabalho masculina foi removida para fins de agricultura colonial. Você pode fazer a história da modernidade como a história do transporte de genes também. De fato, você pode tomar cada uma das células-tronco tecnocientíficas que menciono em Modest_Witness - o cérebro, o chip, o gene, o feto, a bomba, a raça, o banco de dados e o ecossistema, e fazer a história da modernidade.

\footnotetext{
7 "Safras resistentes a herbicidas são provavelmente a maior área de engenharia genética ativa de plantas. Eu me encontro particularmente atraída por estes simpáticos novos seres como o tomate com um gene de um linguado de águas geladas profundas, que codifica para uma proteína que retarda o congelamento, e a batata com um gene do bicho-da-seda gigante, que aumenta a resistência à doença. A DNA Plant Technology (Oakland, Califórnia) começou a testar a combinação anticongelante tomate-peixe em 1991". (HARAWAY, 1997, p. 88).
} 


\section{PRÁTICA MUNDANA}

TNG: O que você quer dizer com "prática mundana"?

DH: Me refiro àquele conjunto implodido de coisas no qual a fisiologia do corpo, o fluxo de sangue e hormônios e as operações químicas - a carnalidade do organismo - se misturam com a vida total do organismo. De forma que, num certo sentido, você pode começar a falar sobre qualquer dimensão daquilo que significa ser mundano - o comercial, o fisiológico, o genético, o político.

TNG: É uma palavra significativa para você, não?

DH: Sim, "mundano" é uma grande palavra para mim. Mas todos esses adjetivos tratam de maneiras de começar a conversar, a trabalhar. Eles são modos de começar a puxar os fios pegajosos nos quais o técnico, o comercial, o mítico, o político, o orgânico estão implodidos.

TNG: Você já usou outras palavras, ou outras pessoas usam palavras para esse mesmo processo? Estou curiosa sobre porque você escolheu a palavra "mundano".

DH: Eu escolhi essa palavra como uma maneira de contornar o debate entre realismo e relativismo. Eu poderia ter dito que "realidade" é a separação entre naturezas e culturas e que eu estou trabalhando na direção de um tipo de realismo melhor, mas isso me apoia em uma série de argumentos equivocados. $\mathrm{E}$ eu sou acusada de ser uma relativista por aqueles que deliberadamente me interpretam mal, o que me deixa muito brava, pois eu me desdobrei para dizer que essa dicotomia particular é parte do problema. Também, dado que meu comprometimento é com coisas como mortalidade e finitude e carnalidade e historicidade e contingência, pareceu-me que "mundano" era uma boa escolha. Mundano também implica em prestar atenção a coisas como poder e dinheiro.

TNG: Certo - e novamente, o motivo pelo qual eu perguntei é porque isso me lembra de Heidegger e de como ele era tão comprometido com o uso de uma linguagem que era do mundo, que era ordinária ou comum. Mundano é uma palavra terrena, uma palavra aterrada. Ela é francamente despretensiosa.

DH: Correto. De certa forma, "situado" foi um esforço parecido de pegar uma palavra comum e tentar fazê-la fazer um certo número de coisas.

TNG: Uma das coisas mais importantes que aprendi com você é uma noção de criticalidade [criticality] que vai além do mero "criticismo" - além da criticalidade didática, diagnóstica. Isso me interessa especialmente, pois 
ultimamente tenho percebido como aquilo que conta como teoria crítica é mais submissa à bistória do que eu jamais havia pensado. Isso provavelmente tem a ver com a minha posição no mundo da arte, onde a arte crítica assumiu todo tipo de diferentes dimensões de geração a geração. Mas recentemente eu me tornei cada vez menos certa sobre o que as pessoas querem dizer por "crítico". Sua noção de criticalidade é notadamente diferente da noção tradicional de crítico, significando desconstruir argumentos e enxergar onde se situa o poder. Significaria "crítico" apenas a posse de um argumento? Estou pensando na arte que, ao produzir novos significados, oferece um avanço crítico - abrindo e produzindo. O trabalbo crítico pode ser uma atividade produtiva, e não apenas negativa. Li recentemente uma maravilhosa distinção que dizia que a teoria deveria fundar a mudança, e não encontrá-la. Tive esse problema na pós-graduação. Eu sempre lia por aquilo que um texto me dava e não por aquilo que ele não me dava, por isso eu constantemente me surpreendia quando "ler" significava que todos deveriam atacar um autor gritando sobre tudo o que ele ou ela deixou de fora. Procurar apenas as falhas ou as ausências parece uma maneira muito estranha de aprender. Na verdade, parece o oposto de aprendizado.

DH: Odeio este modelo.

TNG: E por que as pessoas pensam que essa é a única maneira de ser crítico?

DH: Parte disso é a competição e o medo de parecer tolo se você não fizer a crítica primeiro. De fato, penso que parte das péssimas políticas raciais funciona a partir do mesmo princípio, segundo o qual as pessoas se apressam em acusar os outros de racistas para não serem julgadas elas mesmas. É como se pensassem que o racismo é algo que você pode expelir facilmente por meio de algumas poucas afirmações. Você não pode eliminar racismos por meio de mantras ou apontando como um determinado artigo não lidou com a raça dessa ou daquela maneira, e então relaxar e pensar que está livre por ter notado isso. Em outras palavras, o fato de ter visto te retira de lá. Não são apenas pessoas brancas que têm essa relação com o racismo. E penso que algo desse estilo de crítica negativa na pós-graduação, em relação não apenas ao racismo mas a muitos outros tipos de coisas, está enraizado num medo de aceitar algo com toda a sua bagunça e sujeira e imperfeição. 


\section{ELE NÃO NASCEU NUM JARDIM, MAS CERTAMENTE NASCEU NUMA HISTÓRIA}

TNG: Vamos seguir para o ciborgue, para como você escolheu desenvolver um sistema crítico por meio da produção de novas formulações $e$ relacionamentos a partir dos problemas e contradições - a "bagunça $e$ sujeira" - da vida como a habitamos diariamente. Obviamente, o mito do ciborgue é seu exemplo principal. Uma grande má-interpretação do ciborgue ocorre quando as pessoas não veem sua qualidade generativa, que não é somente uma negação das velhas estruturas de poder (militarismo, Grande Ciência, patriarcalismo, etc.) mas, uma tentativa de ver as coisas diferentemente. Como em sua discussão do gene, o ciborgue não é uma coisa ou um tópico acabado mas, por definição, constantemente transformando $e$ sendo repensado. Ou, como você uma vez colocou, "Ciborgues não ficam parados".

DH: Isto está certo, ele é um tópico aberto e o ciborgue está neste conjunto curioso de relacionamentos familiares com espécies-irmãs de vários tipos. É uma figuração que requer que se pense nos aspectos dos sistemas de comunicação feitos pelo homem, a mistura do orgânico e do técnico que é inescapável nas práticas ciborguianas.

TNG: Há uma tendência para o ciborgue ser deshistoricizado boje em dia. No entanto, é crucial compreender que o próprio ciborgue tem uma história, é um filho de um certo momento da bistória, e portanto ganhará diferentes sentidos e características em relação aos processos históricos.

DH: Definitivamente - ele tem camadas de histórias. Como emprego o termo, sou inflexível que o ciborgue não diga respeito a todos os tipos de relacionamentos maquínicos, artefatuais, com seres humanos. Tanto o humano quanto 0 artefatual possuem histórias específicas. Por um lado, o ciborgue não é a mesma coisa que 0 androide. 0 androide tem de fato uma história muito mais longa. 0 androide surge dos brinquedos mecânicos do século XVIII e do esforço para construir modelos maquínicos, especificamente modelos miméticos de movimento humano. Embora haja um certo tipo de câmara de eco entre 0 androide e 0 ciborgue, certos tipos de continuidades e descontinuidades, me empenho muito para que o termo "ciborgue" seja utilizado para designar

\footnotetext{
8 "Ciborgues não ficam parados. Já nas poucas décadas que eles têm existido, eles, em fato e ficção, alteraram-se em entidades de segunda ordem como bancos de dados genômico e eletrônico e outros habitantes da zona chamada ciberespaço". (HARAWAY, 1995a, p. xix)
} 
especificamente aqueles tipos de entidades que se tornaram historicamente possíveis por volta da Segunda Guerra Mundial e logo após. 0 ciborgue está intimamente envolvido em histórias específicas de militarização, de projetos de pesquisa específicos com ligações com a psiquiatria e a teoria da comunicação, a pesquisa comportamental e a psicofarmacológica, as teorias da informação e 0 processamento de informação. É essencial que o ciborgue seja visto emergindo de tal matriz específica. Em outras palavras, o ciborgue não é "nascido" mas ele tem de fato uma matriz (rindo)! Ou melhor, ele não tem uma mãe, mas ele tem de fato uma matriz! Ele não nasceu num jardim, mas certamente nasceu numa história. E esta história não tem sido suave e tem aproximadamente meio século agora.

TNG: Seria o androide parte da pré-bistória dele?

DH: Sim, mas esta é uma escolha narrativa. Você pode construir uma história contínua na qual o ciborgue é um herdeiro, um sucessor do androide.

TNG: Você poderia fazer uma distinção modernista, pós-modernista?

DH: Poderia, mas, novamente, estas são todas escolhas narrativas. Não é que a própria história determine estas narrativas, mas que as narrativas moldam a história.

TNG: Bem colocado.

DH: Está relacionado com o que falamos antes quando as pessoas engatam somente em um aspecto. Por exemplo, aqueles que relegam o ciborgue a um tipo estranho, atenuado, de euforia tecnofílica ou de amor cintilante a todas as coisas ciber, o que está completamente errado. Ou eles pensam que o ciborgue seja meramente uma figura condenatória, encravado como ele está no militarismo. 0 que me interessa mais sobre o ciborgue é que ele faz coisas inesperadas e responde por histórias contraditórias, permitindo ao mesmo tempo algum tipo de trabalho no e do mundo.

\section{QUANTO COMO UMA FOLHA}

TNG: Falando experiencialmente, qual é seu momento mais profundo de encontrar o que é chamado "ciborgologia" no The Cyborg Handbook (1995a), ou o que poderíamos chamar de "ciborguidade"?

DH: Oh, meu Deus! (Risos)

\footnotetext{
${ }^{9}$ Ver Chris Hables Gray, Steve Mentor e Heidi J. Figueroa-Sarriera (1995).
} 
TNG: Ou quais são os momentos que você se lembra dele se cristalizando para você?

DH: Bem, um é certamente meu sentido de complexidade, interesse e prazer - assim como a intensidade - de como imaginei quanto como uma folha eu sou. Por exemplo, eu sou fascinada com a arquitetura molecular que plantas e animais compartilham, e também pelos tipos de instrumentação, interdisciplinaridade e práticas de conhecimento que entraram nas possibilidades históricas de compreender o quanto eu sou como uma folha.

TNG: Agora, quando você era uma criança, você experienciou tal epifania, ou somente como uma adulta?

DH: Claramente, estou falando de uma perspectiva adulta, especificamente quando me tornei profundamente consciente de momentos de unidade estéticamoral-física que, para mim, foram intimamente influenciados por modos biocientíficos de pensar. Em relação ao encadeamento lógico, a minha consciência infantil era esmagadoramente religiosa. Mas eu era fascinada por miniaturas.

TNG: Miniaturas?

DH: Tudo, de casas de bonecas a imaginar mundos elaborados de pessoas em miniatura e brincar com pequenas figuras na grama. Basicamente, eu simplesmente passei muito, muito tempo em mundos em miniatura.

TNG: Que é o que você ainda faz por meio da biologia molecular e do desenvolvimento e do estudo de sistemas culturais reduzidos em suas menores instâncias. Quando é que a ciência entrou em sua consciência?

DH: Entrou um pouco por meio do ensino secundário de biologia e química. Mas realmente não até a universidade, quando cursava zoologia e, ao mesmo tempo, estudava inglês e filosofia. Todas as três sempre pareceram parte do mesmo assunto.

TNG: Sua teoria se desenvolve tão "naturalmente" a partir de seu interesse em biologia. Mas muitas pessoas no seu campo se sentem bastante ameaçadas pelo modo como você pensa sobre biologia e ciência, o que é irônico dado que você deve sua perspectiva à mais profunda compreensão $e$ corporificação de mundos biológicos. Então, por que tal compreensão é tão ameaçadora?

DH: Parte do desconforto vem do fato de que se você fala sobre a implacável contingência histórica de experienciar a si próprio, ou sobre a manufatura do conhecimento científico, as pessoas ouvem relativismo ou puro 
construtivismo social, o que não é de modo algum o que estou dizendo. Mas este é o tipo de redução que continua sendo feita. E há então as pessoas que se sentem ameaçadas porque leem tais análises como determinismo biológico! Um tipo de naturalismo que elas não querem, pois são construtivistas sociais e não querem dar muito peso ao biológico ou ao natural. Estou tentando dizer ambos, e, nem, tampouco, e então um monte de confusão aparece, e não um tipo muito produtivo de confusão. Estou falando sobre um modo de interação com o mundo que é implacavelmente específico historicamente. A tecnociência é uma semiose materializada. É como nós nos engajamos com e no mundo. 0 que não é a mesma coisa que dizer que o conhecimento é opcional. É dizer que há nele uma especificidade que você não pode esquecer.

TNG: Uma das minhas citações favoritas do "Manifesto" de 1985 é onde você afirma que seu argumento é pelo prazer na confusão das fronteiras e pela responsabilidade na construção delas.

DH: Sim. 0 meu trabalho é ainda interessado em instâncias deste processo.

TNG: Responsabilidade é uma das forças - e substâncias - mais potentes em seu trabalho. De muitas maneiras ela está no centro - se o seu trabalho tem um centro. É o principal ponto de sustentação de suas análises. Você nos ensina a sermos responsivas a todas as complexidades na tecnocultura do final do século $X X$, e então você anexa a esta responsividade os requerimentos da responsabilidade.

DH: Bem, são as pessoas que são éticas, não estas entidades não-humanas.

TNG: Você quer dizer, romantizar o não-bumano?

DH: Certo, este é um tipo de antropomorfização dos atores não-humanos com a qual precisamos ter cautela. Nossa relacionalidade não é do mesmo tipo de ser. São as pessoas que têm responsabilidade emocional, ética, política e cognitiva dentro destes mundos. Mas não-humanos são ativos, não passivos, recursos ou produtos.

\section{Testemunha Modesta}

TNG: É nesta compreensão multidimensional que aparece a sua noção de uma cama de gato, isto é, um estudo da tecnociência anti-racista, feminista, multicultural? 
DH: Esta é uma daquelas formulações impossíveis!

TNG: O que estou perguntando é se a cama de gato é uma outra figura para você, ou é uma metodologia?

DH: Bem, dado que cama de gato é um jogo, suspeito que seja uma metodologia com "m" minúsculo. É um modo de trabalhar e de pensar sobre trabalho, de forma que neste caso ele seja endereçado às pessoas dos estudos da ciência para se valerem mais densamente dos estudos feministas e dos estudos culturais e vice-versa. Cama de gato pode ser jogada em suas próprias mãos, mas é mais interessante jogar com outra pessoa. É uma figura para construir relacionalidade que não seja agonística.

TNG: É similar àquilo que você defende em termos do discurso do sistema imunológico em "The Biopolitics of Postmodern Bodies" usando a série Xenogenesis de Octavia Butler? ? $^{10}$

DH: Sim. Mas é importante que a cama de gato não se torne o modelo singular. Existem algumas práticas tecnocientíficas contra as quais gostaríamos de adotar uma postura oposicionista e antagônica. As metáforas de harmonia e coletividade também não são a estória completa dado que, às vezes, competição e luta e mesmo metáforas militares podem ser o que precisamos. É apenas que a agonística tem sido tão excessivamente enfatizada dentro de muito da tecnociência. Eu estava escrevendo especificamente contra aspectos do livro de Bruno Latour, Ciência em Ação $o^{11}$, que é tão esmagadoramente dependente de metáforas de agonística e combate. A figura da cama de gato é uma resposta direta àquilo. É portanto uma metáfora contextual.

TNG: Descreva seu modelo de tecnociência feminista. Fiz uma lista aqui a partir de Modest_Witness daqueles que parecem ser os traços fundamentais: "tecnociência com democracia", "objetividade forte, uma que seja comprometida com projetos de igualdade humana", é "modesta, universal, abundante", e "constituida de projetos de conbecimento autocríticos".

DH: Sim. Se a tecnociência, em nosso momento na história, é inequivocadamente "natureza" para nós - e não somente natureza mas naturezacultura - então compreender a tecnociência é um modo de compreender como naturezas e culturas se tornaram uma palavra só. Então, a análise da tecnociência,

\footnotetext{
10 "Alguma outra ordem de diferença pode ser possível em Xenogenesis - e em imunologia" (HARAWAY, 1991, p. 227).

${ }^{11}$ Há tradução para o português, ver Latour (2011).
} 
a compreensão de em que tipo de mundo estamos vivendo, é o que chamamos de estudos de tecnociência. Estudos feministas da tecnociência levam a sério aquela lista de coisas que você acabou de ler. Então, isto envolve a liberdade tecnocientífica, a democracia tecnocientífica, a compreensão de que democracia diz respeito ao empoderamento de pessoas que estão envolvidas na montagem e desmontagem de mundos, que processos tecnocientíficos estão lidando com alguns mundos em vez de outros, que a democracia exige que as pessoas estejam substantivamente envolvidas e se saibam envolvidas, e tenham poder para serem cobradas e coletivamente responsáveis umas pelas outras. E estudos feministas de tecnociência passam repetidamente pelas contradições permanentes e dolorosas de gênero.

TNG: "Projeto de conbecimento autocrítico" de fato parece algo que não seria facilmente incorporado no modo como a tecnociência é feita atualmente.

DH: Tecnociência feminista realmente significa ir além dos tipos de instituições que temos agora. Ela está cheia de diferentes tipos de processos de trabalho e de práticas-conhecimento, incluindo a remodelagem do tempo e do espaço. Por exemplo, interagir efetivamente no trabalho, trabalhar com pessoas, realmente envolve repensar o tempo e as carreiras e a velocidade da pesquisa.

TNG: $E$ isto não é necessariamente como a tecnociência está montada no presente?

DH: Certamente não. Processos tecnocientíficos no momento contam com vastas disparidades de riqueza, poder, agência, soberania, oportunidades de vida e morte. Os projetos iluministas para igualdade têm um tipo de saliência modificada dentro da tecnociência hoje. Sou uma filha do Iluminismo; é disso que trata, em grande parte, Modest_Witness. Não estou repudiando a herança de democracia e liberdade e todas aquelas heranças iluministas poluídas. Eu as vejo como que deturpadas. Estou tentando retrabalhá-las.

TNG: Como isto se relaciona com a figura da "testemunha modesta"?

DH: "Testemunha modesta”, junto com OncoMouse ${ }^{\mathrm{TM}}$ e FemaleMan $($, são figuras que uso no livro para representar novos modos de imaginar e de fazer tecnociência. ${ }^{12}$ Em referência a Modest_Witness@Second_Millennium, o leitor vê imediatamente que ela/e é o emissor e o receptor de mensagens em meu

\footnotetext{
${ }^{12}$ Em Modest_Witness, a testemunha modesta representa a estória dos estudos da ciência assim como da ficção científica. FemaleMan $\mathbb{C}$ é a figura mais importante do feminismo. OncoMouse ${ }^{\mathrm{TM}}$ é a figura da biotecnologia e da engenharia genética, uma sinédoque para a tecnociência.
} 
endereço de e-mail. Mas conto também com a complexa história do "testemunhar" e de ser uma "testemunha" dentro das estórias dos estudos da ciência em relação ao desenvolvimento do método experimental por Robert Boyle no século XVII e às controvérsias subsequentes sobre como fatos são estabelecidos crivelmente. Por exemplo, Thomas Hobbes repudiou o modo de vida experimental precisamente porque o conhecimento associado a este modo de vida era dependente de uma prática de testemunho por uma comunidade especial, como aquela dos clérigos e dos advogados. Estou interessada neste tipo preciso de testemunho, pois é sobre ver; atestar; ser publicamente responsável por, e fisicamente vulnerável a, suas visões e representações. Testemunhar é uma prática coletiva, limitada, que depende da credibilidade construída e nunca finalizada daqueles que o fazem, todos os quais são mortais, falíveis e repletos das consequências de desejos e temores inconscientes e rejeitados. Como cria da Sociedade Real da Restauração Inglesa de Robert Boyle e do modo experimental de vida, eu permaneço ligada à figura da testemunha modesta. Minha testemunha modesta é sobre dizer a verdade - dar testemunho confiável - ao mesmo tempo evitando o aditivo narcótico das fundações transcendentais. Ela refigura os sujeitos, os objetos e o comércio comunicativo da tecnociência em diferentes tipos de nós.

\section{TNG: Por que "modesta"?}

DH: "Modesta", como "testemunha", tem uma história profunda e complexa nos estudos da ciência em relação a gênero e aos experimentos de Robert Boyle com a bomba de ar e o desenvolvimento do modo de vida experimental. Retomo a análise de Elizabeth Potter da maneira como o gênero estava em jogo no modo de vida experimental do período dentro do contexto dos debates sobre a proliferação de gêneros na prática do cross-dressing. ${ }^{13}$ Mantenho a figuração de "modéstia" porque o que contará como modéstia agora é precisamente o que está em questão. Há o tipo de modéstia que faz você desaparecer e há o tipo que ressalta sua credibilidade. Modéstia feminina tem sido sobre estar fora do caminho enquanto modéstia masculina tem sido sobre ser uma testemunha crível. E então há o tipo de modéstia feminista (e não feminina) que estou defendendo aqui, que é sobre um tipo de imersão no mundo da tecnociência na qual você faz uma dura intersecção de perguntas sobre raça,

\footnotetext{
${ }^{13}$ Elizabeth Potter, "Making Gender/Making Science: Gender Ideology and Boyle's Experimental Philosophy", em Making a Difference, ed. B. Spanier (Bloomington: Indiana University Press, no prelo). [Nota de revisão: não foi localizada a versão publicada deste artigo. Ver, contudo, POTTER, Elizabeth. Gender and Boyle's law of gases. Bloomington: Indiana University Press, 2001].
} 
classe, gênero, sexo com o objetivo de fazer uma diferença no mundo "materialsemiótico" real.

TNG: O que é então o seu tecnocientista modesto?

DH: Eu nunca usei esta frase exatamente, mas se o fizesse teria que estar relacionada a um tipo de vontade, e habilidade; um afiamento de habilidades, de estar alerta a e abrir o seu trabalho a tipos de prestação de contas que você pode ter resistido anteriormente. Por exemplo, no caso dos pesquisadores genéticos, pedindo a eles para abrir seu trabalho à influência de seus pacientes.

TNG: Modéstia neste contexto é sobre estar alerta para seu impacto, seu poder, seus limites.

DH: Ela não é resignada, entretanto. É, na verdade, um tipo extraordinário de confiança. Modéstia feminista não é alérgica ao poder!

TNG: Exatamente. Pessoas modestas são sempre aquelas nas quais confio. Eu raramente confio em ou respeito pessoas arrogantes, pois arrogância significa um tipo de "estupidez" ensimesmada para mim.

DH: Eu sei o que você quer dizer. E as pessoas também tomam erroneamente modéstia por vitimização por causa do duplo sentido de modéstia a modéstia que é sobre desaparecimento, ou acobertamento, que é mal entendida como incompetência. Modéstia verdadeira é sobre ser capaz de dizer que você tem mesmo certas habilidades. Em outras palavras, ser capaz de fazer afirmações fortes de conhecimento. Não se render ao relativismo estúpido, mas testemunhar, atestar. 0 tipo de testemunha modesta que demando é um que insiste na situacionalidade, onde a localização é ela própria uma construção complexa assim como uma herança. É uma figura que faz suas apostas com projetos e necessidades daqueles que não habitariam ou não poderiam habitar as posições subjetivas dos "laboratórios", do homem civil e crível de ciência. 0 ponto é, Testemunha_Modesta_no_Segundo_Milênio precisa de um novo modo de vida experimental para satisfazer a esperança milenar de que a vida sobreviverá neste planeta. Uma testemunha não é um observador desinteressado, não é um marciano. Penso sobre testemunhar como algo implicado na prática mundana que discutimos anteriormente porque uma testemunha também não é um cérebro-num-vaso. Uma testemunha está sempre em risco de atestar alguma verdade em vez de outras. Você testemunha. Pessoas que vão à Guatemala, Chiapas, Nicarágua ou El Salvador para testemunhar estão fazendo algo que é absolutamente sobre estar engajado. Elas estão também envolvidas no requerimento de dizer a verdade, fazendo-se responsáveis por testemunhar e dizer 
a verdade. Testemunhar, neste caso, é anti-ideológico no sentido de resistir à "estória oficial". Verdade aqui não se escreve com um "V" maiúsculo; i.e., verdade que é transcendente ou fora da história. Ela é resolutamente histórica; atestando as condições de vida e morte.

TNG: Na sua descrição de testemunbar, há um senso próprio de ética.

DH: Definitivamente. E conhecimento científico é sobre testemunhar. 0 método experimental é sobre isto, sobre o fato de estar lá. E o fato de saber certas coisas por estar lá modifica o senso de responsabilidade. Assim, longe de ser indiferente à verdade, 0 enfoque que tento defender é rigorosamente comprometido com testar e atestar. Com se engajar e compreender que este é um empreendimento sempre interpretativo, interessado, contingente, falível. Não é nunca um relato desinteressado.

TNG: Que é a impressão comum de objetividade científica.

DH: Certo, mas objetividade é sempre uma conquista local. Trata-se sempre de manter as coisas juntas bem o bastante para que as pessoas possam participar poderosamente daquele relato. "Local" não significa pequeno ou inapto a viajar.

TNG: Isso me lembra de "Situated Knowledges"' quando você fala sobre localização em um sentido complicado e sobre conbecimento parcial ou perspectiva como o único modo de alcançar "objetividade".

DH: Sim. A testemunha modesta é aquela que pode estar engajada em conhecimentos situados.

\section{OBRAS CITADAS}

BARTHES, Roland. A Lover's Discourse. New York: Hill and Wang, 1978.

EHRENREICH, Barbara e MACINTOSH, Janet. Biology Under Attack. The Nation. Vol. 264, N. 22, 9 de Junho, 1997, p. 11-16.

HABLES GRAY, Chris; MENTOR, Steve; FIGUEROA-SARRIERA, Heidi. Cyborgology: Constructing the knowledge of cybernetic organisms. In: HABLES GRAY, Chris (ed.). The Cyborg Handbook. New York and London: Routledge, 1995.

\footnotetext{
${ }^{14}$ Há versão em português, ver Haraway (1995b).
} 
HARAWAY, Donna. Crystals, Fabrics, and Fields: Metaphors of Organicism in Twentieth-Century Developmental Biology. (New Haven: Yale University Press), 1976.

HARAWAY, Donna. Primate Visions: Gender, Race, and Nature in the World of Modern Science. New York: Routledge, 1989.

HARAWAY, Donna. Simians, Cyborgs, and Women: The Reinvention of Nature. New York: Routledge, 1991.

HARAWAY, Donna. The Promisses of Monsters: Reproductive Politics for Inappropriate/d Others. In: GROSSBERG, Larry; NELSON, Cary; TREICHLER, Paula (eds.). Cultural Studies. New York: Routledge, 1992.

HARAWAY, Donna. Cyborgs and Symbionts: Living Together in the New World Order. In: HABLES GRAY, Chris (ed.). The Cyborg Handbook. New York and London: Routledge, 1995a.

HARAWAY, Donna. Saberes localizados: a questão da ciência para o feminismo e 0 privilégio da perspectiva parcial. Cadernos Pagu (5), 1995b, pp. 07-41.

HARAWAY, Donna.

Modest_Witness@Second_Millennium.FemaleMan $₫$ _Meets_OncoMous $\mathrm{e}^{T M}$ : Feminism and Technoscience. New York: Routledge, 1997.

LATOUR, Bruno. Ciência em ação: como seguir cientistas e engenheiros sociedade afora. São Paulo: Ed. Unesp, 2011.

RAINER, Yvonne. Rainer Talking Pictures: an interview with T.N. Goodeve. Art in America, julho 1997. 